\title{
ОСОБЛИВОСТІ НАЦИСТСЬКОЇ ПОЛІТИКИ ГОЛОКОСТУ НА ЧЕРКАЩИНІ
}

\section{Руденко Ю. М.}

\section{ВСТУП}

Історія Черкащини має багато чорних $\mathrm{i}$ трагічних сторінок. Не обминув iï i Голокост. Під час Голокосту здійснювалось систематичне переслідування і знищення євреїв. Фактично в кожному містечку Черкащини є свій «Бабин Яр», який став символом Голокосту в Україні для мільйонів людей як усередині країни, так і поза іiі межами. Голокост, що призвів до винищення однієї третини євреїв i незліченних жертв із числа представників інших меншин, завжди буде служити застереженням про небезпеку, що несуть ненависть, фанатизм, расизм і упередженість.

Джерельна база роботи включає в себе архівні документи Державного архіву Черкаської області ${ }^{64}$, спогади очевидців ${ }^{65}$, які дають змогу завдяки критичному їх використанню і зіставленню даних, які в них містяться, вирішувати завдання дослідження і досягнути мети. У дослідженні використовуються спогади із матеріалів засобів масової інформації, фондів Чорнобаївського та Золотоніського краєзнавчих музеїв.

Аналіз історіографії дозволяе нам зробити висновок, що комплексної роботи, яка б спеціально досліджувала Голокост на Черкащині не існує, адже в досліджуваний період територія сучасної Черкащини входила до Полтавської і Київської областей. Лише окремі епізоди, які висвітлюють ті чи інші аспекти проблеми, знаходилися в полі зору дослідників.

Публікації в періодичних виданнях «Вісник Городищини» ${ }^{66}$, «Уманський голос» ${ }^{67,68}$, «Рідна Черкащина» ${ }^{69}$ допомагають вивчити різні точки зору на явища, що розглядаються. Значною мірою наше

\footnotetext{
${ }^{64}$ Державний архів Черкаської області. Ф. Р-51. Оп. 1. Спр. 28. 17 арк.

65 Архівний фонд Чорнобаївського районного краєзнавчого музею. Спр. 119. Арк. 1-4.

${ }^{66}$ Щербина М. Неморозька трагедія. Вісник Городищини. 2014. № 4. C. 5. URL: http://www.horodysche.org.ua/?id=307

${ }^{67}$ Оголошення міського комісара Мееде. Уманський голос. 1942. С. 2.

${ }^{68}$ Розпорядження. Уманський голос. 1942. С. 1.

69 Пасічник С. На Черкащині вшанували жертв Голокосту. Рідна Черкащчина. URL: http://ck.ridna.ua/2016/01/27/na-cherkaschyni-vshanuvaly-zhertv-holokostu/
} 
дослідження спирається на праці 3 інтернет-видань: І. Альтман «Неизвестная черная книга» ${ }^{70}$, збірник наукових праць «Сврейський опір в Україні» ${ }^{71}$, Р. Круцик «Українсько-єврейські відносини» ${ }^{72}$, автори яких розглянули як загальні питання проблеми, так і окремі їхні аспекти.

\section{1. Організація злочину на окупованій Черкащині}

\section{1. Заходи окупаційної влади щодо позбавлення сврейського населення громадянських прав}

Відразу після окупації Черкащини німці вдалися до створення нормативно-правової бази знищення євреїв, які оголошувались політичними та расовими ворогами Третього рейху, підвели свої дії під ідеологічне підгрунтя. Встановивши в Україні новий порядок, окупанти в процесі знищення євреїв застосовували особливі методи. Політика державного семітизму в Радянському Союзі унеможливлювала здійснення чіткого обліку жертв, наукових досліджень. У багатьох архівних справах Державного архіву Черкаської області у списках загиблих називаються типові єврейські прізвища та імена, але не вказана національна приналежність ${ }^{73}$. Досліджуючи питання Голокосту на Черкащині, ми враховували, які каральні структури і підрозділи були уповноважені знищувати євреїв, кому була підпорядкована захоплена територія, яка існувала нормативно-правова база забезпечення проведення акцій.

В умовах загального наступу Вермахту розпочалися розстріли вже в перші дні окупації. Захоплена територія переходила у відання військових та цивільних органів влади. Для проведення акцій знищення були задіяні матеріальні і людські ресурси: на території сучасної Черкащини діяли оперативна команда 5, зондеркоманда 4б, що входили до айнзацгрупи Ц, адже особового складу команд поліції безпеки і СД для цього не вистачало ${ }^{74}$. Встановивши свою владу, нацисти

70 Альтман И. Неизвестная черная книга. Иерусалим, 1993. 462 с. URL: http://bookz.ru/authors/il_a-al_tman/neizvest_387/page-8-neizvest_387.html

71 Єврейський опір в Україні в період Голокосту: Збірник наукових статей / За ред. М. Тяглого. Дніпропетровськ: Центр Ткума, 2004. С. 109-110.

72 Круцик Р. Українсько-єврейські відносини, історія і сучасність. URL: http://www.memorial.kiev.ua/statti/1196-ukrajinsko-jevrejski-vidnosyny-istorija-isuchasnist.html

73 Державний архів Черкаської області. Ф. Р-51. Оп. 1. Спр. 28. 17 арк.

74 Гончаренко О. Нацистська політика щодо євреїв. Не підлягає забуттю: наџистський окупаційний режим на Черкащині (1941-1944): збірник наукових статей, документів, матеріалів та спогадів. Черкаси : Ветрикаль, 2013. С. 141. 
систематично почали видавати накази та розпорядження, що стосувалися єврейського населення. Окремі пункти про євреїв містилися практично у всіх важливих наказах, що регламентували життя на захоплених територіях. 3 перших днів окупації був визначений громадянсько-правовий статус євреїв як «неарійців». Це відразу позбавляло їх навіть тих обмежених прав, які мало місцеве населення ${ }^{75}$. У своїх розпорядчих документах німці вживали давню назву для євреїв - жиди. В Україні з 1930-х р. слово «єврей» перестало вважатися офіційним і набуло образливого значення.

Першим із заходів нової влади, який свідчив про особливий статус євреїв, була їх окрема реєстрація та ідентифікація. Населення, яке не встигло або не захотіло евакуюватися, мусило з'явитися на обов'язкову реєстрацію. У міській поліцейській управі м. Черкаси вона тривала до 2 жовтня, всі, хто їі не пройшов, підлягали розстрілу ${ }^{76}$.

Для того, щоб переконати загал, що євреї не такі, як всі, їх зобов'язали носити розпізнавальні знаки на одязі. Для жителів міст Черкаси, Вільшани, Шполи, Звенигородки та деяких інших населених пунктів це були білі пов'язки 3 жовтою шестикутною зіркою на правій руці нижче ліктя ${ }^{77}$. Свреї ж м. Умані були позначені жовтими плямами на спині посередині або зверху та на лівому плечі спереду ${ }^{78}$.

Відповідно до наказу № 9 Управи та інспектора поліції (Головою управління Шпаківським та Інспектором поліції Бомбруком) м. Черкаси від 10 жовтня 1941 р. євреям необхідно було залишити власні помешкання у визначений наказом термін (2 дні) і переселитися на Митницю, де німці створювали гетто ${ }^{79}$. 3 метою організованого переселення окупанти призначили трійцю, до складу якої входили євреї. В обов'язки трійці входило залякування і переконання коритися нацистам. Жителі Митниці мали зайняти звільнені євреями квартири. Свреїв переселяли 3 власних осель, відбирали майно, особисті речі. Зі спогадів М. Файнгольц, жительки м. Умані: «Незважаючи на те, що був установлений строк для переселення, українська поліція нападала й не давала переносити своє майно, вимагаючи негайного виселення 3 квартири. Сиджу в одному українському будиночку, де я ховалася, приходить сусідський хлопчик, синок поліцая, і розповідає про успіхи

75 Альтман И. Неизвестная черная книга. Иерусалим, 1993. С. 57. URL: http:// bookz.ru/authors/il_a-al_tman/neizvest_387/page-8-neizvest_387.html

76 Державний архів Черкаської області. Ф. Р-51. Оп. 1. Спр. 28. Арк. 4.

77 Вишневецкий О. Умань город еврейских страданий и погромов. Проза.ру. URL: https://www.proza.ru/2015/10/24/317

${ }^{78}$ Круцик Р. Українсько єврейські відносини, історія і сучасність. URL: http://www. memorial.kiev.ua/statti/1196-ukrajinsko-jevrejski-vidnosyny-istorija-i-suchasnist.html

79 Державний архів Черкаської області. Ф. Р-51. Оп. 1. Спр. 28. Акр. 6. 
своєї матері, скільки речей вона набрала. Ідучи, він говорить: “Мама дістала собі лише зимове пальто, але вона говорить, що, як тільки будуть ще раз бити жидів, вона дістане собі і літнє пальто”»"

Єврейське населення було виокремлене і при введенні комендантської години. Із серпня 1941 р. уманська міська управа встановила час перебування на вулицях міста для євреїв $з$ 19:00 до 6:00, а для іншого населення - 3 20:00 до 5:00 ${ }^{81}$. На зимові місяці 1942 р. райхскомісар України Е. Кох визначив єдину комендантську годину для єврейського населення з 19:00 до 6:3082.

Обмежувався час відвідання євреями базарів - тільки після 12:00 83 . Згодом їм взагалі заборонили бути учасниками купівлі-продажу: «Ніякий жид не може бути в майбутньому керівником ремісничої або торговельної установи, продаж коштовних речей, меблів та якогось іншого матеріалу жидами українцям забороняється». Свреям закрили доступ до всіх публічних місць продажу, магазинів, готелів, їдалень, базарів, парків, скверів, крамниць та взагалі усіх громадських місць ${ }^{84}$. Iз розпорядження уманського міського управління: «Всі торговельні місця, магазини, крамниці в Умані та в Уманському районі мусять забезпечити себе такими написами: “Жидам вхід заборонено”. Заготівля, написи й приладнання вивісок, а також кошти на це покладаються на жидів» ${ }^{85}$.

Встановивши загальну трудову повинність, окупанти погнали колони євреїв на важкі роботи. Щодня о 7:00 всі євреї м. Черкаси у віці від 15 до 60 років мусили з'являтися на роботу за нарядами, що вони одержували від поліції. Невихід на роботу мав оформлятися через лікаря ${ }^{86}$, інакше прогули суворо каралися. Пізніше з метою збільшення експлуатації робочої сили євреїв у селах Черкащини почали створювати табори праці.

Додатково єврейське населення зобов'язали сплачувати податки. Розміри обов'язкових грошових зборів залежали від розпорядження місцевої влади. Наприклад, 17 жовтня 1941 р. постановою уманського міського управління були визначені розміри державних і місцевих

${ }^{80}$ Назустріч пам'яті: Навч.-метод. посіб. до фільму про Голокост в Україні «Назви своє ім'я» / Авт.-упор.: О. Войтенко, М. Тяглий. К.: Майстер-книг, 2012. С. 139.

${ }^{81}$ Там само. С. 140.

82 Оголошення міського комісара Мееде. Уманський голос. 1942. С. 2.

${ }^{83}$ Там само.

${ }^{84}$ Круцик Р. Українсько єврейські відносини, історія і сучасність. URL: http://www. memorial.kiev.ua/statti/1196-ukrajinsko-jevrejski-vidnosyny-istorija-i-suchasnist.html

${ }^{85}$ Оголошення міського комісара Мееде. Уманський голос. 1942. C. 2.

${ }^{86}$ Круцик Р. Українсько єврейські відносини, історія і сучасність. URL: http://www. memorial.kiev.ua/statti/1196-ukrajinsko-jevrejski-vidnosyny-istorija-i-suchasnist.html 
податків, «жиди, що підлягають оподаткуванню вищезгаданими податками і зборами, сплачують такі в подвійному розмірі» ${ }^{87}$.

Крім економічних утисків, обмежувалися й особисті права. Не дозволялися приватні зв'язки українського населення з євреями й вхід у гетто українцям. Заборонялося «одруження нежидів із жидами» ${ }^{88}$. Свреї позбавлялися права на відбування релігійних обрядів, що підтверджується руйнуванням молитовних будинків та синагог.

Безправне становище єврейського населення підтверджували й такі розпорядження управи поліції м. Черкаси: «За кожного вбитого робітника нової влади, розстрілу підлягають 50 жидів та 10 комуністів; за кожний спалений будинок розстрілу підлягають 100 жидів та 20 комуністів» ${ }^{89}$.

Окупанти попереджали i українське населення про заборону надавати допомогу чи ховати євреїв. Відповідно до розпоряджень німецької влади, за «переховування жидів та зв'язок із партизанами винні розстрілюватимуться на місці без суду» ${ }^{90}$.

Як бачимо, щодо євреїв застосовувалася політика дискримінації, їх позбавляли прав громадян за національними ознаками, релігійними переконаннями.

Введення окупантами таких обмежень було зумовлено бажанням принизити людську гідність самих євреїв та переконати загал, що вони не такі, як всі, а гірші. Суть запроваджуваних окупаційною владою заходів полягала в підготовці майбутнього знищення, яке відрізнялося лише термінами проведення.

\section{2. Форми опору українців і євреїв політиці нацистів на Черкащині}

Незважаючи на жорстокість німецького законодавства щодо переслідування євреїв, вони прагнули вижити в нелюдських умовах, всупереч не тільки волі окупантів, а й навколишньому оточенню. Найпоширеніші визначення термінів «опору» та «протистояння» дав історик Д. Міхман. «Протистояння» він визначив як здійснення якихось активних дій із метою самозбереження, на відміну від бездіяльності і покірності. Протистояння $€$ опором намірам влади, воно містить різні аспекти - економічний, релігійний, культурний, організаційний. Термін «опір» у контексті Катастрофи використав для

${ }^{87}$ Круцик Р. Українсько єврейські відносини, історія і сучасність. URL: http://www. memorial.kiev.ua/statti/1196-ukrajinsko-jevrejski-vidnosyny-istorija-i-suchasnist.html

${ }^{88}$ Там само.

${ }^{89}$ Державний архів Черкаської області. Ф. Р-51. Оп. 1. Спр. 28. Арк. 7.

90 Оголошення міського комісара Мееде. Уманський голос. 1942. С. 2. 
позначення збройних дій ${ }^{91}$. Проте в гетто Черкащини більшість в'язнів становили люди похилого віку, діти, жінки, непрацездатні особи. Чоловіки призивного віку були в армії або загинули в перших акціях. Нацисти ввели жорстку систему колективної відповідальності й заручників. Тому чинити активний опір і підпільну діяльність було майже неможливо.

Проте відомий факт умілих і ефективних дій підпільника єврея Зигмунта Гросбарта 3 м. Умані. За завданням підпільної організації, яка виникла в с. Тальянки поблизу м. Тального, він написав німецькою мовою нібито від імені німецького господарського управління прохання в жандармерію м. Тального видати зброю для охорони цього управління. Таким чином, у руках підпільників, які готувалися до збройної боротьби, було в наявності 20 гвинтівок і сотні патронів. За їх допомогою були звільнені з табору полонені, знищено німецький літак на аеродромі, проведено успішні бої проти окупантів у Зеленій Брамі. У свідченнях, які зберігаються в Яд Вашем, 3. Гросбарт істотно доповнює факти про свою антифашистську діяльність. Він, як працівник вузла зв'язку, затримав дві телеграми, в яких управління поліції просило про допомогу людьми і озброєнням для боротьби з партизанами ${ }^{92}$.

Багато людей брали участь у непомітній повсякденній боротьбі 3 нацистами та їхніми посібниками. Не хотіли коритися німецьким законам навіть діти. М. Гольдберг народилася в м. Умані 1930 р. У дівчинки було щасливе дитинство в дружній родині. Батька Марії призвали на фронт у перші дні війни, він загинув майже одразу. У 10 років Марія пережила перший погром у іiі рідному місті, ховаючись із незнайомими людьми у підвалі. Ї̈̈ бабусю, маму та сестру вбили у 1941 р. Представляючись «не єврейкою», Марія втекла в найближе с. Сушківка, де працювала помічницею в господарстві. Попереджена місцевим поліцаєм П. Дегтяренком про арешт, Марія погодилася піти з ним до с. Баланка, де вона жила з родиною Петра до моменту визволення Радянською армією у 1944 p. ${ }^{93}$

Звіти айнзацгруп характеризують основні форми протистояння євреїв, які здійснювали саботаж, лише імітували виконання роботи, ховали розпізнавальні знаки, переховувалися, уникали ідентифікації, ухилялися від реєстрації, втікали чи не з'являлися на місця збору до переселення в гетто. Найбільш радикальною формою протистояння була втеча від розстрілу під час перевезення до місця страти чи втеча 3 колони. Накази

91 Єврейський опір в Україні в період Голокосту : збірник наукових статей / за ред. М. Тяглого. Дніпропетровськ : Центр Ткума, 2004. С. 109.

92
93
Там само. С. $109-110$. 
про реєстрацію та переселення в гетто порушували багато євреїв. Але лише завдяки цьому їм вдалося вижити. Багато переховувалося на віддалених хуторах та селах, бродили лісами в пошуках їжі та безпеки. Втікачі часто змінювали багато адрес і населених пунктів, пересиджували в стогах сіна, запущених будівлях. Особливо численними були спроби зникнути з місця страти. Люди вистрибували з поїздів і машин, вибиралися 3 могили після завершення акції, деякі стрибали в рови чи ями перед пострілами, інші були легко поранені, хтось уцілів під мертвими тілами. Ю. Пінчук, герой кінострічки С. Буковського «Назви своє ім'я», народився в м. Шполі 1930 р. Юрій із трьох років виховувався батьками неньки, після того як його батьки розлучилися. Коли м. Шпола була окупована німецькими військами у 1941 р., будиночок родини Юрія займала німецька адміністрація, а родину насильно переселили в гетто. У 1942 р. всіх євреїв, які лишилися в гетто м. Шполи, перегнали в концентраційний табір у с. Дар'ївці, де їх знищили через кілька днів після прибуття. Юрію вдалося втекти незадовго до масових розстрілів, але його мати 3 двома дітьми від другого шлюбу й бабуся загинули. Юрій жив за підробленими документами ${ }^{94}$.

Найчастіше рятувалися діти і підлітки. Їх українські родини могли назвати своїми, дати українські імена. Напередодні окупації німцями Черкас 22 серпня 1941 р. М. Мамченко 3 дітьми намагалася евакуюватися на схід. Їх потяг потрапив під бомбардування, Марія була поранена, а iï новонароджений син загинув. Родина Мамченко повернулася в окуповане місто. Через поранення Марія довго не могла повернутися до роботи, тому вся відповідальність за сім'ю лягла на плечі іï одинадцятирічного сина Валентина. Одним із його обов'язків були щоденні візити в сім'ю М. Гершунової - сусідки і подруги М. Мамченко. Маня і троє іiі дітей, які не підкорилися наказу німців про переселення в гетто, залишилися в своїй квартирі. Маня намагалася видавати себе за росіянку, що перебуває в шлюбі з євреєм, який служив у Червоній Армії. Це виходило, допоки хтось із сусідів не доніс на них, і вся сім'я була заарештована. Коли всіх єврейських жителів Черкас вели до місця масового розстрілу на околиці міста, Маня несла свою п'ятирічну дочку Лідію на руках. Раптом вона побачила в натовпі Марію, гукнула ii по імені, і коли їх погляди зустрілися, швидко нахилилася i опустила Лідію на тротуар. Марія схопила дитину i кинулася додому ${ }^{95}$.

94 Єврейський опір в Україні в період Голокосту : збірник наукових статей / за ред. М. Тяглого. Дніпропетровськ: Центр Ткума, 2004. С. 109.

95 Наш рідний край. Хрестоматія 3 історії Черкащини. Ч. 2. / Упоряд : А. Кузьмінський, Г. Суховершко, В. Чудновський. Київ : Молодь, 1995. С. 118. 
Якщо в дітей була відсутня явно виражена семітська зовнішність $\mathrm{i}$ акцент, їх віддавали в дитячі будинки і притулки. Відомо, що в Черкасах у період німецької окупації діяв притулок. Його 3 власної ініціативи організувала О. Шулежко. Коли почалася війна, жінка не змогла евакуюватися - на руках було двоє маленьких дочок 4 і 7 років. Одного разу, йдучи по місту, Олександра побачила маленького хлопчика біля тіла мертвої матері. Вона взяла дитину і привела до себе додому. Так у неї з'явилася думка врятувати осиротілих дітей, яких холодної осені 1941 р. було багато на черкаських вулицях.

Коли дітей зібралося досить багато, Олександра, знаючи трішки німецьку мову, пішла в німецьку комендатуру просити дозволу організувати притулок. Виявилося, що цей німець-комендант теж був сиротою і виріс у дитячому будинку. Він відгукнувся на прохання допомогти, однак за однієї обов'язкової умови: в притулку не має бути єврейських дітей, інакше розстріляють усіх.

До того часу у О. Шулежко зібралося вже близько 100 дітей від 3 до 16 років, з яких 25 були євреї. Вона не могла від них відмовитися. Тому дала єврейським дітям інші прізвища, імена, національності і суворо заборонила розповідати про своє минуле. I, напрочуд, ніхто з дітей за весь час не проговорився.

11 червня 1996 р. О. Шулежко присвоєно почесне звання Праведник народів світу. Її ім'я викарбовано на Стіні Пам'яті Алеї Праведників народів Світу ${ }^{96}$. У м. Черкаси встановлена пам'ятна дошка.

Про факт вияву опору нацистам свідчать дії щодо уникнення депортації В. Блакитної. Німці окупували с. Кищенці Маньківського району у серпні 1941 р., і через місяць всі місцеві євреї були депортовані 3 села. Тільки двадцятишестирічна В. Блакитна була єдиною єврейкою села, яка сховалася і не була депортована. Кілька односельчан знали, що Валентині вдалося уникнути депортації і вона ховається неподалік від села. Ночами Валентина поверталася в село i стукала в двері своїх колишніх сусідів, просячи трохи їжі. Одного вечора вона постукала у двері будинку А. Шимко, і оскільки на вулиці було дуже холодно, попросила переночувати. Анна запросила іiі в будинок, і ця одна ніч розтяглася більш ніж на два роки - аж до звільнення регіону в березні 1944 р. Цей випадок підтверджує і опір української жінки, яка не корилася заборонам окупаційної влади i переховувала єврейську жінку ${ }^{97}$.

96 Юрківська Т. Праведник Клавдія Шулежко. URL: http://ukr-vestnik.com/ interesting/lydi/350-v-rezultate-aleksandra-shulezhko-sdrabivshhiny-priyutila-sotni-osiro tevshix-detej.html

97 Пасічник С. На Черкащині вшанували жертв Голокосту. Рідна Черкащчина. URL: http://ck.ridna.ua/2016/01/27/na-cherkaschyni-vshanuvaly-zhertv-holokostu/ 
Серед 35-40 мільйонів українців знайшлося чимало інтелігентів, простих селян і міщан, які, ризикуючи своїм життям, надали притулки сотням і тисячам євреїв. Однак ці випадки були більш винятком, ніж правилом. Назагал українське суспільство переважно хоча й співчувало долі євреїв, але не наважувалося надати їм допомогу. В умовах німецької окупації, коли українцям і полякам за це загрожував розстріл, кожен такий акт був виявом особистої відваги, що межувала 3 героїзмом.

Під час війни В. Дикий жив у м. Смілі. В одній зі смілянських шкіл викладала вчителька М. Зимня. Сусіди повідомили німецьку владу, що вона єврейка. Її з донькою мали заарештувати. Віктор зі своєю мамою відвезли їх в с. Ташлик до надійних людей. Необхідно було здобути для них документи. 15-річний Віктор встиг до війни попрацювати слюсарем. Забравшись до приміщення Смілянської залізничної лікарні, він відкрив сейф, в якому зберігались документи тих, хто загинув, підібрав найнадійніші для Марії Зимньої та іiї доньки. Із цими документами мама 3 дочкою дісталися до Румунії, де і прожили до кінця війни ${ }^{98}$.

Серед жителів м. Золотоноша були такі, хто виявляв милосердя, співчуття до приречених на смерть євреїв i, всупереч наказам нацистів, рятували. Їх по праву можна назвати праведниками. О. Олександрова 3 родиною рятувала на своєму Куличівському хуторі (тепер це частина с. Новодмитрівка) молоду єврейку, яка тікала від війни із заходу України. Також були врятовані корінні жителі міста Л. Сендеров, М. Колінько, О. Гімельфарб, М. Пілявський ${ }^{99}$.

Аналізуючи випадки порятунку євреїв, прослідковуються факти, пов'язані 3 українською поліцією. Колаборування 3 будь-яким окупантом дає шанси вижити. У роки Другої світової війни колаборація набрала тотального характеру. На окупованих нацистами східних територіях до участі в окупаційній адміністрації допускалася обмежена кількість представників місцевого населення. Саме в поліцаїв було найбільше можливостей рятувати єврейське населення. Їхні дії викликали менше підозри з боку нацистів. Т. Шнайдер, дівчину із Неморозького табору праці, врятував випадок і добра душа поліцая П. Микитенка. Таня згадує: «Він нас впізнав. Одвів на садибу свого батька, що була поруч із його хатою; а там у нього був льох і курінь над ним, обтягнутий дошками. Каже: "Ви маленькі - сидіть, поміститесь.

98 Пасічник С. На Черкащині вшанували жертв Голокосту. Рідна Черкащина. URL: http://ck.ridna.ua/2016/01/27/na-cherkaschyni-vshanuvaly-zhertv-holokostu/

99 Голиш Г. Документи. Спогади. Статті. Золотоніщина в роки Великої Вітчизняної війни 1941-1945 рр. Черкаси : Відлуння-плюс, 2000. С. 32. 
Якщо підпалять - не панікуйте, спустіться в льох і накрийтесь”. На ранок почули гавкіт собак, але пси обминали курінь. Поліцаї вистрелили по куреню і пішли. А Павло став підшукувати нам інший притулок, адже літо закінчувалося. Павло сам був агрономом, приносив нам часто їжу, іноді, напевно, беручи у інших людей. Він підтримував зв'язок із партизанським загоном і весь урожай картоплі, пшениці переправляв туди. Нам також допомагав поліцай Фока, приносячи їжу, яку ми з Сонею ділили. Настали пізні осінні холоди. Інколи випадав сніг. Переховування у погребі ставало неможливим. Замерзали, ледве приходили до тями» ${ }^{100}$. Господарі забрали дівчат на піч, щоб відігріти. Заварювали лікувальні трави і крапали дівчатам у рота. Цілий тиждень лікувалися. Врятували дівчат батьки поліцая Павла. Потім переховувалися в різних ямах. Одна була зовсім вузька і тісна, ледве можна було поміститися. Згодом перейшли у просторішку яму в сараї. Біля ями ставили корову, щоб менше було підозр. Виникла потреба перевезти дівчат в інше село. Поліцай Фока загорнув їх у снопи, поклав на підводу і повіз. Біля лісу зупинилися в якомусь сараї. Та господар сараю їх знайшов і направив у село, в якому не було німців. Дав їм їжу i теплий одяг ${ }^{101}$.

Під час розстрілу євреїв у м. Золотоноша врятувався завдяки поліцаю М. Корженевський. В кінці колони їхали вози, на яких сиділи каліки, діти, старі та немічні. I тільки випадково один із поліцаїв викинув його з гурту. Якимось дивом він опинився вдома - а це зовсім близько до того провалля, де за якусь мить почалися розстріли усіх тих людей, що 3 ними разом він пробрів кількадесят метрів через Струнківку ${ }^{102}$.

Отже, нацисти 3 перших днів окупації підвели свої злочинні дії під ідеологічне підгрунтя, вони вдалися до створення нормативно-правової бази знищення євреїв. Окупанти в процесі здійснення політики Голокосту застосовували особливі методи. Політика державного семітизму в Радянському Союзі унеможливлювала здійснення чіткого обліку жертв, здійснення наукових досліджень. Таким чином, євреї опинилися в таких обставинах, що не давали можливості їм активно протидіяти нацистам і забезпечити збереження життя. Вони були деморалізовані безнадійністю свого становища, втратами членів родин, близьких. Військово-адміністративна машина Третього рейху виробила

${ }^{100}$ Щербина М. Неморозька трагедія. Вісник Городищиини. 2014. № 4. C. 5. URL: http://www.horodysche.org.ua/?id=307

101 Там само.

102 Голиш Г. Документи. Спогади. Статті. Золотоніщина в роки Великої Вітчизняної війни 1941-1945 рр. Черкаси : Відлуння-плюс, 2000. С. 32. 
систему заходів із ліквідації євреїв, здобула і зміцнила досвід антисемітських дій у країнах Свропи. Своїми наказами та розпорядженнями вони виключали євреїв із соціального середовища.

У створених на Правобережній Черкащині гетто більшість в'язнів становили люди похилого віку, діти, жінки, непрацездатні особи. Адже чоловіче населення призивного віку були в армії або були знищені в перших акціях. Нацисти ввели жорстку систему колективної відповідальності й заручників. Тому чинити активний опір і підпільну діяльність було майже неможливо.

Таким чином, багато людей брали участь у непомітній повсякденній боротьбі з нацистами та їхніми посібниками. Проте лише окремі могли протистояти каральному апарату - вони уникали реєстрації та ідентифікації, ховалися, тікали в села, бродили лісами, дотримувалися національно-релігійних звичаїв, здійснювали саботаж, лише імітували виконання роботи, ховали розпізнавальні знаки, тікали під час розстрілів, брали в руки зброю, втікали чи не з'являлися на місця збору до переселення в гетто. Найбільш радикальною формою протистояння була втеча від розстрілу під час перевезення до місця страти чи втеча 3 колони. Опір нацистському режиму чинили і українці, які під загрозою смерті переховували євреїв, рятували, піклувалися, ділилися останнім.

\section{2. Створення гетто і таборів примусової праці}

\section{1. Умови утримання сврейських громадян в гетто}

Важливою особливістю Голокосту на Правобережній Черкащині було створення гетто, тобто виділення частини території населеного пункту для примусового утримання осіб єврейської національності. Причинами створення гетто була велика кількість євреїв, що проживали на території Черкащини. Гетто були створені у містах Черкаси, Звенигородка, Умань, Сміла, Шпола, Монастирище. Адже згідно з переписом населення 1939 р. у Умані проживало 13 233, Черкасах - 7637, Смілі - 3428, Тальному - 1866, Шполі - 2397, Корсуні - 1329, Звенигородці - 1957 євреїв ${ }^{103}$.

Гетто на Черкащині були не типовими, вони не мали юденратів, які мали б забезпечити реєстрацію населення гетто, організувати забезпечення продовольством і медичним обслуговуванням мешканців гетто; не було власної адміністрації та поліції.

103 Гончаренко О. Нацистська політика щодо євреїв. Не підлягає забуттю: нащистський окупаційний режим на Черкащині (1941-1944) : збірник наукових статей, документів, матеріалів та спогадів. Черкаси: Ветрикаль, 2013. С. 145-146. 
Значні відмінності в процесі створення гетто Черкащини, що базувались на критеріях расової сегрегації та дискримінації, дають змогу визначити високий рівень правотворчості уповноважених суб'єктів місцевих органів влади. Найбільше гетто діяло у м. Умані. Із серпня 1941 р. жити євреям міста дозволялося тільки в окремому районі (базар із прилеглою територією) ${ }^{104}$.

Про механізм його створення свідчить відповідне оголошення у місцевій пресі. В оголошенні міського комісара Мееде 28 лютого 1942 р. зазначалося:

1. Всі торговельні місця, магазини, крамниці в Умані та в Уманському районі мусять забезпечити себе такими написами: «Жидам вхід заборонено».

2. Всі під'їдні дороги до Гетто мусять мати напис: «Увага! Гетто! Вхід українцям заборонено під загрозою штрафу».

3. Заготівля, написи й приладнання вивісок, а також кошти на це покладається на жидів. Термін 27.02.1942 р.

4. Зараз після публікації цього забороняю я всяку самостійну торгівлю й ремісництво жидам, тобто ніякий жид не може бути в майбутньому керівником ремісничої або торговельної установи.

5. Зараз же, після опублікування цього, забороняю я продаж коштовних речей, меблів та якогось іншого матеріалу жидами українцям, тобто: купівлю або присвоєння жидівського майна українцями. Хто протидіятиме ухвалі від 1 до 5 пункту, буде оштрафований ${ }^{105}$.

Лише це гетто мало штат працівників, що призначався 3 числа євреїв. Окрім старости, був його помічник та кілька поліцаїв. Під час виплати контрибуцій староста разом із поліцаями нещадно знущалися над багатими євреями, вимагаючи видачі цінностей ${ }^{106}$.

Євреїв примушували носити жовті нашивки на грудях та спині. Весь жах того існування підсилювався тим, що мешканцям гетто не давали їжі. Тому люди були приречені на болісну голодну смерть. Спочатку міняли на їжу все, що можна було обміняти в людей, які приходили до огорожі. Але з часом міняти вже було нічого. 3 усіх, хто ще здатен був стояти на ногах, німці вибирали тих, хто, на їхню думку, міг працювати, і відправляли на ремонт дороги Вінниця - Кіровоград, а також на каторжну роботу в каменоломні.

104 Шварцман Ш. Єврейське життя в Умані. URL: http://04744.info/istoriyaumani/item/2469-yevrejske-zhyttya-v-umani-chastyna-6

105 Оголошення міського комісара Мееде. Уманський голос. 1942. С. 2.

106 Гончаренко О. Нацистська політика щодо євреїв. Не підлягає забуттю: нацистський окупаційний режим на Черкащині (1941-1944) : збірник наукових статей, документів, матеріалів та спогадів. Черкаси : Ветрикаль, 2013. С. 148. 
1 жовтня 1941 р., підкоряючись німецькому наказу, уманська сім'я Дудник перемістилися в гетто, організоване поруч із міським ринком. Мешканцям гетто суворо заборонялося покидати його територію, проте голод змусив сестер Дудник вийти за огорожу і просити знайомих українців допомогти їм 3 їжею. Коли вони дісталися до будинку Ларжевських, ті забезпечили їх продуктами, але, крім того, переконали залишитися в них переночувати. Наступного ранку, 8 жовтня, в гетто була проведена Акція, і батьки Раїси та Валентини загинули разом із тисячами інших євреїв ${ }^{107}$.

Німці під загрозою розстрілу забороняли українцям надавати їжу для в'язнів гетто. Проте є факти, що свідчать про прояви людяності і милосердя до ув'язнених. У жовтні 1941 р., через два місяці після початку окупації Умані, німці розстріляли більшість євреїв в яру під назвою Сухий Яр, за межею міста. Серед убитих були Ципа Гайсинська та її син Михайло, в той час як чоловік Ципи, Григорій, їхній старший син Борис були залишені живими в числі кількох фахівців, чиї вміння ще потрібні були окупантам. Наприкінці 1941 р. Григорій із сином познайомилися з Мотроною Коваль, молодою вдовою-українкою, яка іноді приносила їжу в'язням гетто. Відгукнувшись на благання Григорія, Мотря сховала у себе Бориса після його втечі з гетто ${ }^{108}$.

Єврейське населення м. Звеногородка було сконцентроване в гетто на вул. Пролетарській, частково Гулькіна та Комсомольській ${ }^{109}$. Ця ділянка не була обгороджена, але патрулювалася.

Кілька будинків із глухим парканом навпроти обозного заводу утворювали Монастирищенське гетто. Будинки були позначені шестикутними зірками та пронумеровані. Завдяки тому, що окупанти потребували кваліфікованої робочої сили, це гетто проіснувало майже рік.

Євреїв м. Корсунь тримали під конвоєм в будинку по вул. Ремісничій (зараз - Короленка). Їм нашили білі значки та морили голодом.

В'язнем Вільшанського гетто стала Т. Шнайдер. Їй вдалося вижити в страшних умовах у Неморозькому таборі праці. У Вільшані гетто почало існувати з 29 серпня 1941 р. Вона згадує процес формування гетто: «Зігнали нас на вулицю у кілька будинків. У нас розмістилися всі родичі мами. Кожного дня нас виводили на найтяжчі роботи - мили цистерни для бензину, казарми, я носила воду. Якось жандарм нам

107 Наш рідний край. Хрестоматія 3 історії Черкащини. Ч. 2 / Упоряд: А. Кузьмінський, Г. Суховершко, В. Чудновський. Київ : Молодь, 1995. С. 118.

108 Вишневецкий О. Умань город еврейских страданий и погромов. Проза.ру. URL: https://www.proza.ru/2015/10/24/317

109 Гончаренко О. Нацистська політика щодо євреїв. Не підлягає забуттю: нацистський окупаційний режим на Черкащині (1941-1944) : збірник наукових статей, документів, матеріалів та спогадів. Черкаси : Ветрикаль, 2013. С. 149. 
сказав: “Хочете, я увімкну радіо, і ви дізнаєтеся, де ваші війська?” Наші були далеко. Нам оголосили вимогу здати сімейне золото, і якщо хтось намагався щось доводити - забирали дітей. Я бачила як вели одного чоловіка за непокору, кинувши його до вбиральні.

У жовтні 1941 р. провели першу акцію - зібрали всіх чоловіків і розстріляли за селом (і досі ми не знаємо місця страти). Перебули зиму на своїх запасах. Нам не дозволялося спілкуватися з українцями, ходити на базар. 5 травня 1942 р. нас вигнали з будинків, зібрали біля школи і повели в Звенигородську тюрму. Діти плакали, за завісою жінки справляли пологи, не було води, замість туалету стояло спільне відро. Нас нікуди не випускали. А на ранок почалося сортування матерів із маленькими дітьми і стариків погнали в гетто на вулицю Гулькіна, де вони пробули до червня 1942 р., а нас, молодих, вишикували і погнали невідомо куди» ${ }^{110}$.

Тетяну разом із батьками і молодшим братом було переправлено до табору праці в с. Неморож поблизу Звенигородки. А найменший брат разом із бабусею залишився у Звенигородському гетто.

«Палестиною» німці принизливо називали гетто у м. Шполі, засноване у вересні 1941 р. Його квартали були обтягнуті дротом, електрика не постачалася ${ }^{111}$. Свреї носили пов'язки. Їм заборонили відвідували базар. Хліб не видавали, а населення поза гетто отримувало по двісті грам щодня, за це сплачували по двісті рублів. Дуже скоро в гетто почався голод і щодня помирали десять-дванадцять осіб ${ }^{112}$.

До 12 жовтня окупанти утворили гетто в м. Черкаси на Митниці. 3 часом було створено ще одне відділення гетто. Для нього було вибрано приміщення колишнього гуртожитку деревообробного комбінату, з широким подвір'ям, що розташовувалося на розі вулиць Островського та Дніпровського шосе. Сюди переселяли євреїв із Подолу і Митниці ${ }^{113}$. Ліквідація гетто відбувалася у 1942 р., в окремих випадках у 1943 p. $^{114}$

${ }^{110}$ Щербина М. Неморозька трагедія. Вісник Городищиини. 2014. № 4. C. 5. URL: http://www.horodysche.org.ua/?id=307

${ }^{111}$ Пасічник С. На Черкащині вшанували жертв Голокосту. Рідна Черкащина. URL: http://ck.ridna.ua/2016/01/27/na-cherkaschyni-vshanuvaly-zhertv-holokostu/

${ }^{112}$ Гроссман В., Эренбург И. Черная книга. Київ, 1991. С. 123.

113 Пасічник С. Після окупації в Черкасах діяли два гетто. IнфоMICT. URL: http://infomist.ck.ua/pislya-okupatsiyi-v-cherkasah-diyaly-dva-getto/

114 Гончаренко О. Нацистська політика щодо євреїв. Не підлягає забуттю: нащистський окупаційний режим на Черкащині (1941-1944) : збірник наукових статей, документів, матеріалів та спогадів. Черкаси : Ветрикаль, 2013. С. 149. 


\section{2. Табори примусової праці на Правобережній Черкащині}

Складовою частиною злочинної діяльності нацистів на окупованій Черкащині була жорстка політика примусової праці для євреїв. Табори примусової праці для євреїв були місцем фактичного їх ув'язнення 3 метою використання на тяжких роботах. Вони створювались на основі гетто, або були спеціально створеними 3 вивезених із гетто працездатних євреїв. Табори були підпорядковані керівництву поліції та СС. На території окупованих східних областей України їх створювали відповідно до розпорядження рейхсміністра про введення примусової праці для євреїв ${ }^{115}$. Через сотні таборів пройшло близько мільйона людей, більшість 3 яких загинули. Це була одна із форм масового знищення євреїв шляхом непосильної праці. За суворістю утримання ці табори наближалися до концтаборів. У всіх таборах на території окупованої України спостерігалася висока смертність, голод, відсутність медичної допомоги, тортури, знущання над в'язнями, масові знищення.

На Черкащині в'язнів таборів праці використовували в основному під час ремонту та будівництва доріг. Зокрема, цим займалися євреї Лисянського району, яких помістили в табір у с. Будищі. Тут разом із дітьми знаходилося 170 осіб. Люди жили в колишній колгоспній стайні, яку ретельно охороняли. Щодня їх гонили на непосильні земляні дорожні роботи за 20 км від табору ${ }^{116}$. В'язні ремонтували дорогу, взимку очищали ії від снігу, в інші пори року - від бруду і сміття. Крім цього, місцеві поліцейські змушували працювати євреїв ще й в особистих господарствах. У разі спроби втечі ув'язнених розстрілювали на місці ${ }^{117}$.

2 травня 1942 р. євреїв із гетто м. Вільшани погнали до м. Звенигородка. Їх розмістили на ніч у в'язниці, а наступного дня відібрали та відправили в звенигородське гетто дітей, людей похилого віку і хворих. Усіх працездатних у віці від 12 років перевели в табір у с. Смільчинці Лисянського району. Умови життя в таборі були нестерпними, люди жили в свинарниках, спали на голій землі або на перегної, який залишився від худоби і свиней. Харчувалися один раз на добу - отримували баланду і сто грамів хліба 3 проса. Виживали

115 Гісем О., Мартинюк О. Голокост в Україні (1941-1944). Словник-довідник. Вид. 6-е. Київ : Український центр вивчення історії Голокосту, 2012. С. 13.

116 Альтман И. Неизвестная черная книга. Иерусалим, 1993. С. 182. URL: http://bookz.ru/authors/il_a-al_tman/neizvest_387/page-8-neizvest_387.html

117 Швейбиш С. Принудительный труд евреев во время Шоа (Холокоста) на Украине (1941-1944). URL: http://jewishkrasilov.org.ua/kbp/prinuditelnyj-trud-evreevvo-vremya-shoa-xolokosta-na-ukraine-1941-1944 
завдяки продуктам, що давали їм в'язні гетто м. Звенигородка ${ }^{118}$. Ув'язнені очищали та ремонтували дорогу від Звенигородки до Лисянки, валили ліс, корчували пеньки ${ }^{119}$. У кам'яному і піщаному кар'єрах дробили щебінку і тягали каток замість коней. Періодично окупанти відбирали та розстрілювали ослаблених. Одяг загиблих привозили в табір та роздавали в'язням. Вже 2 листопада цього ж року 50 євреїв розстріляли, а 100 відправили до табору в с. Неморож Звенигородського району ${ }^{120}$.

Першими ув'язненими Неморозького табору 5 травня 1942 р. стали працездатні євреї із Звенигородського гетто. За весь період існування тут перебувало 819 євреїв. Місце для табору було вибрано недалеко від траси, якою пересувалися німецькі війська в напрямі на м. Київ. Свреї утримували іiі в ідеальному стані, щоб не було ні найменших вибоїн. Відпочивали та спали в стайні на соломі. Їли баланду раз на день. В основному працювали на дорозі, а тих, хто міцніший, посилали в кам'яний кар'єр розбирати й вантажити камені після вибухів. Взимку розчищали снігові замети, збивали дерев'яні щити, ставлячи їх біля дороги. На роботу ходили за 10-12 км під охороною поліцаїв. Інколи німці проводили акції з відбору хворих й ослаблених.

Умови перебування в Неморозькому таборі описує Т. Шнайдер: «У Неморозькому таборі праці, який було облаштовано в колишній колгоспній стайні, почалися жахливі випробування на життя і смерть. Одержавши кирки і лопати, почали працювати на ремонті доріг, корчували пні, працювали у пісочному та кам'яному кар'єрах, валили ліс. Повертаючись у табір і заставши тишу, розуміли - відбулась акція. Годували нас тільки ввечері, їжа - одні відходи із стружкою... А поряд 3 нашею стайнею був свинарник. Ми спали на тих відходах, що й худоба. Найтяжча робота була в кар'єрі, працювали без рукавиць. Руками розбивали каміння, а військовополонені, які були там, тут же його укладали. Ми з ними спілкувались. Місцеві жителі нам трохи допомагали їжею: підкидали по дорозі цукрові буряки, картоплю, яку перевозили. Ми їх їли, але завжди були голодні. Ми ніколи не роздягалися, лежали хто де. Грілися один поруч з іншим, якщо спина

118 Гончаренко О. Нацистська політика щодо євреїв. Не підлягає забуттю: наџистський окупаџійний режим на Черкащині (1941-1944) : збірник наукових статей, документів, матеріалів та спогадів. Черкаси: Ветрикаль, 2013. С. 149.

119 Альтман И. Неизвестная черная книга. Иерусалим, 1993. С. 182. URL: http://bookz.ru/authors/il_a-al_tman/neizvest_387/page-8-neizvest_387.html

120 Швейбиш С. Принудительный труд евреев во время Шоа (Холокоста) на Украине (1941-1944). URL: http://jewishkrasilov.org.ua/kbp/prinuditelnyj-trud-evreevvo-vremya-shoa-xolokosta-na-ukraine-1941-1944 
захолола, то інша дівчина поверталася лицем та зігравала своїм подихом. Отак і виживали - хотілось вціліти» ${ }^{121}$.

Подібні роботи виконували євреї таборів в с. Єрки Катеринопільського району та в с. Талалаївці Христинівського району ${ }^{122}$.

Оскільки трудові табори були тимчасовим місцем утримання євреїв до розстрілу, німці планували акції їх знищення. Над в'язнями табору 2 листопада 1942 р. була вчинена чергова акція. Проте це був день, коли Т. Шнайдер вдалося уникнути смерті. Вона згадує: «Відібрали окремо всіх чоловіків і жінок, наказали взяти кирки, мовляв, потрібно відремонтувати частину дороги, яка провалилася. Молодший брат побіг за нашим батьком. Потім відібрали ще 10 людей, серед яких і мене; видали нам лопати, кажучи, що на допомогу іншим. 3 того десятку вціліли тільки я та військовополонений М. Хуторянський. Ми прийшли у ліс і почули стрілянину. Нарахували 50 пострілів. За нами йшов поліцай. Підійшли ближче, на інший бік і почули крики, побачили щось страшне - був іній, ожеледиця, слизько, а людей били і роздягали по дорозі. Поліцай сказав: “Дівчата, туди не йдіть, вони свідків не залишають. Там $\epsilon$ друга яма. Ви засиплете першу, а потім розстріляють вас”. “Куди ж нам діватися?” - питаємо. “Сидіть тут, вони поїдуть, тоді і ви йдіть”. Пройшов час, на машину завантажили одяг і вона поїхала, а ми тихенько пішли, але не по дорозі, а лісом. Геть стемніло; фашисти розвантажили одяг і пішли пиячить. Розстріли проходили на стику трьох сіл, у лісі, що його називають Діброва. 3 моїх рідних, котрі повернулися у табір, зосталася двоюрідна сестра Соня та мама. Наступного ранку вцілілих в'язнів відправили у с. Будище. Розмістили в розваленому клубі - без даху і дверей. Місцевий староста був добрим. Жаліючи дівчат він підкидав їм їжу й давав чисту солому. Та й спали не на вогкій землі, а на дошках. Навіть жартували: “Спимо, як на перині”. В'язні розчищали дорогу від сильних заметів, інколи розводили вогнище і грілися» ${ }^{123}$. У березні 1943 р. Тетяна і Софія знову повернулися до Неморожу. Продовжувалась та ж сама шляхова робота. Дівчата знали, що невдовзі їх можуть розстріляти, адже радянські війська наближались до Дніпра. Готувались до найгіршого. Проте в душі сподівались на те, що виживуть. 23 серпня 1943 р. прийшли нові поліцаї. Вони погнали частину дівчат на роботу в поле - збирати

${ }^{121}$ Щербина М. Неморозька трагедія. Вісник Городищини. 2014. № 4. C. 5. URL: http://www.horodysche.org.ua/?id=307

122 Швейбиш С. Принудительный труд евреев во время Шоа (Холокоста) на Украине (1941-1944). URL: http://jewishkrasilov.org.ua/kbp/prinuditelnyj-trud-evreevvo-vremya-shoa-xolokosta-na-ukraine-1941-1944

${ }^{123}$ Щербина М. Неморозька трагедія. Вісник Городищчини. 2014. № 4. С. 5. URL: http://www.horodysche.org.ua/?id=307 
урожай гороху, а потім сушити і заготовляти тютюн. Через кілька днів їм не привезли їжу і дівчата пішли у табір, а там - порожньо, тільки одна прибиральниця. Таня і Соня, з хитрощами і ризиком для життя, пройшли через село і сховалися в кущах біля річки. Надвечір їх почали шукати ${ }^{124}$.

Існували табори, де євреї працювали тільки в кар'єрах-каменоломнях. Один із таких був ус. Буки Маньківського району, де перебували жителі м. Жашкова, с. Маньківки та с. П'ятигір. 3 табору поліцаї гнали євреїв на кар'єр Буки - Антонівка, де каменярі кололи скелі, а в'язні вагонетками возили і складали у штабелі камінь. Потім його відправляли на будівництво доріг ${ }^{125}$.

Інший схожий табір існував ус. Іскрене Шполянського району. 3 травня 1942 р. в'язнями табору були 300-500 євреїв зі Шполи і Звенигородки. Їх розмістили у свинарниках та обгородили колючим дротом. Знесилених в'язнів розстрілювали. Ймовірно, такі акції проводилися два рази. У першій акції загинуло 30-35 євреїв, у другій 7-8. Наприкінці листопада 1942 р. табір припинив своє існування ${ }^{126}$.

Таким чином, особливістю Голокосту на Правобережній Черкащині було створення гетто, тобто виділення частини території населеного пункту для примусового утримання осіб єврейської національності. Причинами створення гетто була велика кількість євреїв, що проживали на території Черкащини.

Значні відмінності в процесі створення гетто Черкащини, що базувались на критеріях расової сегрегації та дискримінації, дають змогу визначити високий рівень правотворчості уповноважених суб'єктів місцевих органів влади. Найбільше гетто діяло в м. Умані. Для в'язнів гетто були спеціально розроблені правила, дотримуючись яких людина могла лише померти. Крім голодної смерті, нацисти здійснювали акції знищення.

Відповідно до нацистської ідеології, на основі розпорядження рейхсміністра про введення примусової праці для євреїв, створювалися трудові табори. У таборах знаходилося працездатне населення, в основному молодь. Табори примусової праці для євреїв стали місцем фактичного їх ув'язнення з метою використання на тяжких роботах. Вони створювались на основі гетто, були підпорядковані керівництву поліції та СС. Через

${ }^{124}$ Щербина М. Неморозька трагедія. Вісник Городищини. 2014. № 4. С. 5. URL: http://www.horodysche.org.ua/?id=307

125 Горошко С. Жашківщина: історія в долях учителів і учнів. Умань, 2004. C. 101 .

${ }^{126}$ Швейбиш С. Принудительный труд евреев во время Шоа (Холокоста) на Украине (1941-1944). URL: http://jewishkrasilov.org.ua/kbp/prinuditelnyj-trud-evreevvo-vremya-shoa-xolokosta-na-ukraine-1941-1944 
сотні таборів пройшло близько мільйона людей, більшість 3 яких загинули. Це була одна із форм масового знищення євреїв шляхом непосильної праці. За суворістю утримання ці табори наближалися до концтаборів. Ці табори стали ланками єдиної системи, в основі якої був сконструйований конвеєр смерті. На окупованих східних територіях табори праці мали найбільш жорстокий характер. У всіх таборах на території окупованої України спостерігалася висока смертність, голод, відсутність медичної допомоги, тортури, знущання над в'язнями, масові знищення. Іноді табори існували паралельно з гетто. Вони створювалися поряд із дорогами, підприємствами та іншими об’єктами будівництва.

\section{3. Остаточне вирішення нацистами сврейського питання на Черкащині. Масові розстріли}

Розстріли єврейського населення розпочалися 3 перших днів окупації на основі «Указу про комісарів» від 7 липня 1941 р. За цим нормативним актом проходили вбивства єврейської інтелігенції та євреїв чоловічої статі. У серпні 1941 р. особисто А. Гітлером та Г. Герингом був підписаний наказ про тотальне знищення євреїв, що проживало на території СРСР. 3 цього часу євреїв почали знищувати незалежно від віку і статі. Розстріли проводилися в усіх місцях компактного проживання єврейського населення.

У м. Черкаси досить точно визначені місця, де у серпні 1941 р., створили два гетто - Митницьке і Подільське, які ліквідували 18 грудня 1941 р. Загальна кількість загиблих оцінюється у 8 тисяч осіб ${ }^{127}$.

Під час Другої світової війни м. Умань протягом двох із половиною років було окуповано німецькими військами. Наслідки окупації були для євреїв катастрофічні. Найбільш масові розстріли на території сучасної Черкащини були проведені саме в Умані та Уманському районі. До Другої світової війни Умань славилася євреями-ювелірами, шевцями, кравцями, трудилися цілі династії євреїв-лікарів, адвокатів, учителів, викладачів вищих навчальних закладів. Разом із представниками інших національностей євреї забезпечували стабільну роботу міста, його життєдіяльність і розвиток. 16 серпня 1941 р. під приводом підготовки точного перепису єврейського населення Умані та його передмість, німці разом з українською поліцією зібрали та розстріляли в районі аеродрому близько 6000 осіб ${ }^{128}$. У цьому ж році,

127 Гончаренко О. Нацистська політика щодо євреїв. Не підлягає забуттю: нацистський окупаційний режим на Черкащині (1941-1944): збірник наукових статей, документів, матеріалів та спогадів. Черкаси : Ветрикаль, 2013. С. 144.

${ }_{128}$ Вишневецкий О. Умань город еврейских страданий и погромов. Проза.ру. URL: https://www.proza.ru/2015/10/24/317 
22 та 23 вересня, у Сухому Яру від розстрілів загинуло ще 1412 євреїв, а 24 вересня у підвальному приміщенні будинку по вул. Леніна 11000 громадян було отруєно газом ${ }^{129}$. За даними Державного архіву Черкаської області, було розстріляно та поховано більше 15 тисяч євреїв $^{130}$. На цьому місці встановлено пам'ятний знак.

За роки окупації в братських могилах міста, які знаходяться в Сухому Яру та в Собківському лісництві, було розстріляно більше 20 тисяч євреїв не тільки з Умані, але й 3 інших населених пунктів Уманського району. Ця вражаюча цифра становить $80 \%$ від загальної кількості мирного населення Уманського району, загиблого в період Другої світової війни.

Наступний погром проти євреїв Умані розпочався 8 жовтня 1941 p. $^{131}$. Після нього в місті залишилося 1800 євреїв, 3 якими розправилися у квітні $1942 \mathrm{p}$.

У селах Уманщини відомо два місця кровопролиття. Одне з них поблизу с. Гродзеве в Горбовому (Гереженівському) лісі, де загинуло до 10000 осіб мирного населення, серед яких цигани, військовополонені, але більшість - євреї. Інше - Цибулівський Яр (поруч 3 автодорогою Київ - Одеса). Зі свідчень старожилів с. Ладижинки відомо, що німці та українська поліція затримали та розстріляли кілька єврейських родин, загалом 14 осіб, які намагалися евакуюватися 3 с. Тернівка ${ }^{132}$.

Розправи над єврейським населенням Тального відбувалися 16-18 серпня 1941 р. у трьох місцях: біля с. Білашка (територія глинища) - розстріляно близько 2800 євреїв; у м. Тальне, в районі нинішньої вул. Комунальної - понад 1600; біля бойні (поле біля с. Здобутки Жовтня) - знищили тих євреїв, які тікали з Вінницької області. Продовжувалися вбивства і у 1942 р., зокрема 6 квітня $-115^{133}$, 17 квітня ще близько 100 осіб $^{134}$. Свреїв збирали хитрістю оголошували, що їх переведуть до Одеси, звідки пароплави повезуть їх на землю Обітованну, де буде єврейська держава. Враховуючи всі

129 Гончаренко О. Нацистська політика щодо євреїв. Не підлягає забуттю: нащистський окупаџійний режим на Черкащині (1941-1944) : збірник наукових статей, документів, матеріалів та спогадів. Черкаси: Ветрикаль, 2013. С. 144-145.

${ }^{130}$ Державний архів Черкаської області. Ф. Р-51. Оп. 1. Спр. 28. Арк. 13.

131 Вишневецкий О. Умань город еврейских страданий и погромов. Проза.ру. URL: https://www.proza.ru/2015/10/24/317

132 Савін О. Історія села Ладижинки. URL: https://books.google.com.ua/books/ about/ Історія_Ладижинки_Оле.html?id=KwiqCAAAQBAJ\&redir_esc=y

133 Гончаренко О. Нацистська політика щодо євреїв. Не підлягає забуттю: нащистський окупаџійний режим на Черкащині (1941-1944): збірник наукових статей, документів, матеріалів та спогадів. Черкаси: Ветрикаль, 2013. С. 147.

${ }^{134}$ Гроссман В., Эренбург И. Черная книга. Київ, 1991. С. 129. 
акції проти населення, у Тальному жертвами нацизму стали понад 5 тисяч євреїв ${ }^{135}$.

У серпні 1941 р. на Капалайденій горі (за 3 км на північний схід від м. Лисянка) було розстріляно єврейське населення Лисянського району. Тоді загинуло більше 300 євреїв, зокрема із с. Боярка - чотири сім’і Л. Гершка, Н. Дубового, Г. Гонопольського та А. Бенеміна; с. Бродок Ф. Склярська та ії двоє дітей; с. Писарівка - А. Константинівський; с. Виноград - 155 осіб; решта із Лисянки ${ }^{136}$.

На території Корсунщини євреїв знищували: в урочищі «Кущаївка» близько 1000 жителів Корсунь-Шевченківського, Канівського та Богуславського районів, у районі «Різаного Яру» - кілька тисяч, у смт Стеблево в урочищі «Довжик» по вул. Подільській -143 особи $^{137}$.

У Монастирищенському районі є 3 місця масових розстрілів євреїв. У с. Терлиця були розстріляні місцеві євреї і біженці з Києва, Гайсина, Дашева. Місце поховання не зазначено. 29 травня 1942 р. в урочище Поперечний Яр (Бурлаків ліс) були зігнані євреї з містечок Сарни, Лукашівка, Цибулів, Монастирище, Дашів, Гайсин, Ільїнець та розстріляні. Наприкінці 1942 р. було розстріляно більше 6000 осіб за будівлею Райагробуду в Монастирищі. У краєзнавчому музеї є списки, в яких значиться близько 1000 осіб.

У передвоєнні роки у м. Звенигородці мешкало 7840 євреїв - майже половина населення містечка. Сврейська община мала синагогу, два молитовних будинки, бібліотеку, однокласне початкове училище, приватні чоловіче і двоє жіночих училищ, свої школи та лікарні. Відомі кілька місць загибелі єврейського народу. На східній околиці міста в долині (на лівому березі) річки Погибної розташоване урочище Лаптева левада. Тут встановлено місце поховання (7 могил) радянських громадян, розстріляних у роки окупації. На «Губській дачі» - в лісі на 15-му км дороги Звенигородка - Лисянка відбувся наймасовіший розстріл 17 липня 1942 р. Із загальної кількості 3500 розстріляних встановлені імена та прізвища 650 осіб. Ще чотири братських могили виявлені в урочищі Діброва Хлипнівського лісництва на схід від Звенигородки на відстані 200 м від траси. У цих могилах покояться розстріляні бранці Звенигородського гетто, мирне населення, навіть 200 дітей, комуністи і комсомольці, підпільники, жителі не тільки

135 Пасічник С. На Черкащині вшанували жертв Голокосту. Рідна Черкащина. URL: http://ck.ridna.ua/2016/01/27/na-cherkaschyni-vshanuvaly-zhertv-holokostu/

${ }^{136}$ Гончаренко О. Нацистська політика щодо євреїв. Не підлягає забуттю: нацистський окупаційний режим на Черкащині (1941-1944) : збірник наукових статей, документів, матеріалів та спогадів. Черкаси: Ветрикаль, 2013. С. 144-145.

${ }^{137}$ Пасічник С. На Черкащині вшанували жертв Голокосту. Рідна Черкащчина. URL: http://ck.ridna.ua/2016/01/27/na-cherkaschyni-vshanuvaly-zhertv-holokostu/ 
Звенигородського, а й Шполянського, Лисянського, Катеринопільського районів. Загалом близько 2500 осіб, серед яких 1400 євреїв ${ }^{138}$.

Місцем розстрілу мирних жителів у м. Канів є Берестовецький Яр по вул. Київській, де з серпня 1941 по січень 1944 рр. за свідченнями очевидців загинуло близько 1200 жителів, у тому числі євреїв.

У Городищенському районі жертвами окупаційної влади стали 300 євреїв, яких 29 березня 1942 р. розстріляли поблизу урочища Садстанція не далеко від Млієва. Про трагедію в Млієві згадує очевидець Н. Ласкава: «Це було весною 1942 р. До села гнали колону євреїв. Вони з усіх боків були оточені поліцаями. Була вирита довга яма. Побачивши ii, люди зрозуміли, що це кінець. Прикладами, палицями і кулаками людей примусили стати вздовж ями в кілька рядів. Почали стріляти 3 кулеметів. Багато поліцаїв під час розстрілу поховались за нашою хатою і сараєм. Один із них закрив вуха і плакав, але більшість із них брала участь у розправі. Стріляли самі, а потім добивали ранених в ямі. Після розстрілу поліцаї зібрали розкидані речі на вози. Потім зігнали чоловіків села, щоб загорнути яму» ${ }^{139}$. Розстріл єврейського населення організовано за наказом Городищенського начальника жандармерії обер-лейтенанта Остер при безпосередній участі і керівництві начальника української поліції Носарєва, сільськогосподарського коменданта Фельдмана, перекладача Ланге, заступника начальника поліції Жук. Безпосередньо розстріл здійснювали особовий склад сільських поліцій разом із німецьким каральним загоном ${ }^{140}$.

На південно-східній околиці смт Маньківки в напрямі руху до с. Іваньки, у 1942 р. окупанти замордували близько 50 осіб єврейської національності, а в урочищі Дубинка поблизу м. Христинівки з 1941 по 1944 pp. - від 100 до 200 осіб, більшість єврейської національності.

Близько 1000 євреїв поховано у братській могилі, що знаходиться у Дар'ївському парку м. Шпола.

Розстріли євреїв відбувалися і в Жашківському районі - на території сіл Скибин, Конела, Вороне, Сорокотяга ${ }^{141}$

Не обминули події Голокосту і лівобережні райони Черкаської області. Вже в перші дні окупації здійснювалися каральні акції. На Лівобережній Черкащині гетто не створювались, найбільше єврейського населення проживало в Золотоноші (до 50\% перед війною).

138 Пасічник С. На Черкащині вшанували жертв Голокосту. Рідна Черкащина. URL: http://ck.ridna.ua/2016/01/27/na-cherkaschyni-vshanuvaly-zhertv-holokostu/

139 Наш рідний край. Хрестоматія 3 історії Черкащини. Ч. 2 / Упоряд:

А. Кузьмінський, Г. Суховершко, В. Чудновський. Київ : Молодь, 1995. С. 118.

${ }^{140}$ Там само.

141 Пасічник С. На Черкащині вшанували жертв Голокосту. Рідна Черкащина. URL: http://ck.ridna.ua/2016/01/27/na-cherkaschyni-vshanuvaly-zhertv-holokostu/ 
Розстріли відбувалися в ярах, де зручно було загорнути землею трупи i приховати сліди злочину. Незначна кількість населення проживала в селах - найбільше в с. Гельмязів. Проте ніхто з євреїв не уник страти. Ïx разом із сільськими активістами, партактивом відвозили до Золотоноші і там вбивали. У центрі міста встановлено Меморіал жертвам фашизму, серед яких і багато євреїв. У цій братській могилі тіла 12750 жителів Золотоніського, Драбівського, Іркліївського i Чорнобаївського районів.

Багато золотонісців та жителів інших міст єврейської національності було вбито фашистами і на території бурякопункту ${ }^{142}$.

22 листопада 1941 p. німецький карний загін гітлерівців під керівництвом начальника гестапо майора Клауса, начальника польової жандармерії лейтенанта Рейнекке, командира військ СС штурмбанфюрера Франца, начальника поліції Золотоніської округи фейдфебеля Каланчука організували звірячу розправу над єврейським населенням.

Напередодні розстрілу німецьким командуванням було наказано єврейському населенню 3 усіма цінностями, грішми, кращим одягом 3'явитися 22 листопада 1941 р., о 9:00 до приміщення гестапо для евакуації в м. Кременчук. У цей же день по всіх вулицях міста була розставлена варта $з$ поліцаїв, які робили ретельні обшуки в мешканців квартир, де жило єврейське населення, а також і в сусідніх будинках. Тих, що поховалися в ямах, окопах, льохах поліція витягувала i приводила до визначеного пункту. Прохання, сльози жінок, старих, дітей не змогли викликати людське почуття в безсердечних зрадників батьківщини - поліцаїв ${ }^{143}$.

Усі речі, гроші, цінності, гарний одяг гестапівці відібрали у своїх жертв. Приречених на смерть погнали у північно-східну частину міста (Струнківку). Тут, на віддалі трьох кілометрів від міста, у глибокому яру, було розстріляно понад 3500 осіб, серед яких були старі, жінки, діти.

Крики, стогін приреченого на смерть населення було чути за кілька сот метрів, вони розривали серця мешканців міста. Очевидець зазначених звірств, мешканець м. Золотоноші В. Куць розповів: «У листопаді 1941 р. я особисто бачив зі свого двору, як німці разом із поліцаями гнали за місто мирне населення. Чулись під ударами розпачливі крики дітей i дорослих, їх гнали до кручі, а там розстрілювали. Під час розстрілу лунали дитячі одчайдушні крики: "Мама, папа, спасіть нас" - гітлерівці не звертали уваги, розстрілювали

142 Голиш Г. Документи. Спогади. Статті. Золотоніщина в роки Великої Вітчизняної війни 1941-1945 pр. Черкаси : Відлуння-плюс, 2000. С. 32-33.

${ }^{143}$ Там само. 
матерів і дітей. ...після цього я бачив, як німці вивозили в місто одяг $\mathrm{i}$ цінні речі розстріляних. Через три дні я оглянув місце розстрілу i побачив розкидані, розірвані радянські гроші, фотокартки, дитячі шапочки і другі речі» ${ }^{144}$.

Трагічна доля і євреїв Чорнобаївщини. На Чорнобаївщині жорстоко закатували фельдшера С. Чемеринську i iї двох дітей Аллу i Володимира за те тільки, що Софія була єврейка. Закатували серед білого дня на вигоні біля школи, вбили дітей, а потім і матір ${ }^{145}$.

В архіві збереглися дані, що 28 вересня 1941 р. у с. Мельники Чорнобаївського району було розстріляно німцями єврейську сім'ю Мінциківських. Їх вивели за лікарню в кущі бузку і наказали батькові копати могилу. Матір і трьох дітей розстріляли на місці. А його повели аж у соснові посадки і там убили. Селяни довго не могли оговтатися від такого звірства ${ }^{146}$.

Не можна стверджувати, що наведений перелік місць, де відбувалося масове знищення єврейського населення на території Черкаської області, є остаточним. Те ж саме стосується і кількості загиблих. Це пов'язано з тим, що дуже часто євреїв розстрілювали та ховали не окремо, а разом із радянськими активістами, представниками руху опору, ромами та іншим мирним населенням. Це показує не лише фізичні дії, а й духовну та моральну позицію, яку євреї демонстрували під нацистською окупацією ${ }^{147}$.

Духовне неозброєне протистояння мало велике моральне значення. Прагнення зберегти життя своє і своїх рідних було найбільш масовою формою протистояння.

Таким чином, масові розстріли єврейського населення розпочалися 3 перших днів окупації на основі «Указу про комісарів» від 7 липня 1941 р. Відповідно до цього нормативного акта проходили вбивства єврейської інтелігенції та євреїв чоловічої статі. У серпні 1941 р. особисто А. Гітлером та Г. Герингом був підписаний наказ про тотальне знищення євреїв, що проживало на території СРСР. 3 цього часу євреїв почали знищувати незалежно від віку і статі.

Основною формою знищення єврейського населення Черкащини були масові розстріли. Їх організовували або відкрито і сплановано, або приховано, тобто збирали населення під приводом перевезення до

144 Голиш Г. Документи. Спогади. Статті. Золотоніщина в роки Великої Вітчизняної війни 1941-1945 pp. Черкаси : Відлуння-плюс, 2000. С. 32-33.

145 Архівний фонд Чорнобаївського районного краєзнавчого музею. Спр. 119. Арк. 1.

146 Там само. Арк. 3.

147 Єврейський опір в Україні в період Голокосту: Збірник наукових статей / За ред. М. Тяглого. Дніпропетровськ : Центр Ткума, 2004. С. 109. 
Палестини або в інший регіон. Німецькою владою визначалися пункти збору, встановлювався перелік речей, які необхідно взяти, як правило, це були кошти чи коштовні речі, дорогий одяг. Свреїв знищували разом iз радянськими полоненими чи комуністами, тому точну кількість людей єврейської нації встановити досить складно. Вже в перші дні окупації здійснювалися каральні акції. На Лівобережній Черкащині, де євреїв проживало не так багато, як на Правобережній, гетто не створювались. Розстріли відбувалися в ярах, недалеко від населеного пункту, де зручно було загорнути землею трупи і приховати сліди злочину.

Близькість проведення акцій до житлових масивів не виключала наявності свідків, давала хоч найменшу надію втекти по дорозі i заховатися в людей. Розстріли проводилися в усіх місцях компактного проживання єврейського населення. Найбільш масові розстріли на території сучасної Черкащини були проведені в Умані та Уманському районі.

\section{ВИСНОВКИ}

Опрацювавши наявну джерельну та історіографічну базу, можемо зробити висновок, що особливостями Голокосту на Лівобережній Черкащині були: відсутність депортацій до таборів смерті за межі району, розстріли в ярах, найближчих до місць проживання, відсутність масового опору, відкритість нацистських заходів, масовість акцій тотального знищення, перебування євреїв в особливому соціальноправовому становищі, дискримінація, використання каральних органів, намагання знищити свідчення організованого геноциду і пам'яті про нього. Тут євреїв знищували швидко і безкарно. Розстріли проводилися в усіх місцях компактного проживання єврейського населення.

У районах Правобережної Черкащини у зв'язку з великою кількістю єврейського населення і неможливістю їх перевезення до концтаборів спостерігаємо створення гетто в колишніх місцях проживання єврейського населення. Їх ізолювали від інших жителів, обгородивши колючою проволокою, позбавивши можливості спілкуватися й отримати допомогу ззовні, позбавивши задоволення елементарних потреб - харчування. На Правобережній Черкащині євреїв ув'язнювали і в таборах примусової непосильної праці на будівництві і в кам'яних кар'єрах.

Незважаючи на переслідування і знищення, люди єврейської національності знаходили в собі сили чинити опір у непомітній повсякденній боротьбі $з$ нацистами та їхніми посібниками. Не хотіли коритися німецьким законам навіть діти. Основними формами протистояння євреїв були саботаж, вони лише імітували виконання роботи, ховали розпізнавальні знаки, переховувалися, уникали ідентифікації, 
ухилялися від реєстрації, втікали чи не з'являлися на місця збору до переселення в гетто. Найбільш радикальною формою протистояння була втеча від розстрілу під час перевезення до місця страти чи втеча 3 колони. Накази про реєстрацію та переселення в гетто порушували багато євреїв. Але лише завдяки цьому їм вдалося вижити. Серед українців знайшлося чимало інтелігентів, простих селян і міщан, які, ризикуючи своїм життям, надали притулки сотням і тисячам євреїв.

\section{АНОТАЦІЯ}

У статті на основі наявної джерельної та літературної бази визначено особливості нацистської політики Голокосту на Черкащині. Проаналізовано заходи окупаційної влади щодо позбавлення єврейського населення громадянських прав. Встановлено форми опору політиці нацистів із боку єврейського населення, окреслено роль українського населення у порятунку євреїв. Визначено особливості створення гетто і таборів примусової праці, умови їх функціонування та утримання єврейських громадян. Досліджено механізм знищення євреїв на території сучасної Черкаської області.

\section{ЛІТЕРАТУРА}

1. Альтман И. Неизвестная черная книга. Иерусалим, 1993. 462 с. URL: http://bookz.ru/authors/il_a-al_tman/neizvest_387/page-8-neizvest_387.html

2. Архівний фонд Чорнобаївського районного краєзнавчого музею. Спр. 119. Арк. 1-4.

3. Вишневецкий О. Умань город еврейских страданий и погромов. Проза.py. URL: https://www.proza.ru/2015/10/24/317

4. Гісем О., Мартинюк О. Голокост в Україні (1941-1944). Словникдовідник. Вид. 6-е. Київ : Український центр вивчення історії Голокосту, 2012. $100 \mathrm{c}$.

5. Голиш Г. Документи. Спогади. Статті. Золотоніщина в роки Великої Вітчизняної війни 1941-1945 рр. Черкаси : Відлуння-плюс, 2000. C. 32-33.

6. Гончаренко О. Нацистська політика щодо євреїв. Не підлягає забуттю: наиистський окупаиійний режим на Черкащині (1941-1944) : збірник наукових статей, документів, матеріалів та спогадів. Черкаси : Ветрикаль, 2013. С. 141-154.

7. Горошко С. Жашківщина: історія в долях учителів і учнів. Умань, 2004. C. 101.

8. Гроссман В., Эренбург И. Черная книга. Киев, 1991. 560 с.

9. Державний архів Черкаської області. Ф. Р-51. Оп. 1. Спр. 28. 17 арк. 
10. Сврейський опір в Україні в період Голокосту: Збірник наукових статей / За ред. М. Тяглого. Дніпропетровськ : Центр Ткума, 2004. C. 109-110.

11. Круцик Р. Українсько-єврейські відносини, історія і сучасність. URL: $\quad$ http://www.memorial.kiev.ua/statti/1196-ukrajinsko-jevrejskividnosyny-istorija-i-suchasnist.html

12. Назустріч пам'яті: Навч.-метод. посіб. до фільму про Голокост в Україні «Назви своє ім'я» / Авт.-упор.: О. Войтенко, М. Тяглий. К.: Майстер-книг, 2012. С. 139-140.

13. Наш рідний край. Хрестоматія 3 історії Черкащини. Ч. 2 / Упоряд: А. Кузьмінський, Г. Суховершко, В. Чудновський. Київ : Молодь, 1995. С. 118.

14. Оголошення міського комісара Мееде. Уманський голос. 1942. C. 2.

15. Пасічник С. Після окупації в Черкасах діяли два гетто. ІнфоМІСТ. URL: http://infomist.ck.ua/pislya-okupatsiyi-v-cherkasah-diyaly-dva-getto/

16. Пасічник С. На Черкащині вшанували жертв Голокосту. Рідна Черкашина. URL: http://ck.ridna.ua/2016/01/27/na-cherkaschyni-vshanuvalyzhertv-holokostu/

17. Розпорядження. Уманський голос. 1942. С. 1.

18. Савін О. Історія села Ладижинки. URL: https://books.google.com.ua/ books/about/Iсторія_Ладижинки_Оле.html?id=KwiqCAAAQBAJ\&redir_ esc $=\mathrm{y}$

19. Шварцман Ш. Єврейське життя в Умані. URL: http:// 04744.info/istoriya-umani/item/2469-yevrejske-zhyttya-v-umani-chastyna-6

20. Швейбиш С. Принудительный труд евреев во время Шоа (Холокоста) на Украине (1941-1944). URL: http://jewishkrasilov.org.ua/ kbp/prinuditelnyj-trud-evreev-vo-vremya-shoa-xolokosta-na-ukraine-1941-1944

21. Щербина М. Неморозька трагедія. Вісник Городищини. 2014. № 4. C. 5. URL: http://www.horodysche.org.ua/?id=307

22. Юрківська Т. Праведник Клавдія Шулежко. URL: http:// ukr-vestnik.com/interesting/lydi/350-v-rezultate-aleksandra-shulezhko-sdra bivshhiny-priyutila-sotni-osirotevshix-detej.html

\section{Information about the author:} Rudenko Yu. M.,

Candidate of Historical Sciences, Associate Professor at the Department

of Social Sciences and Humanities Kyiv Cooperative Institute of Business and Law 18, Lomonosova str., Kyiv, 03022, Ukraine 